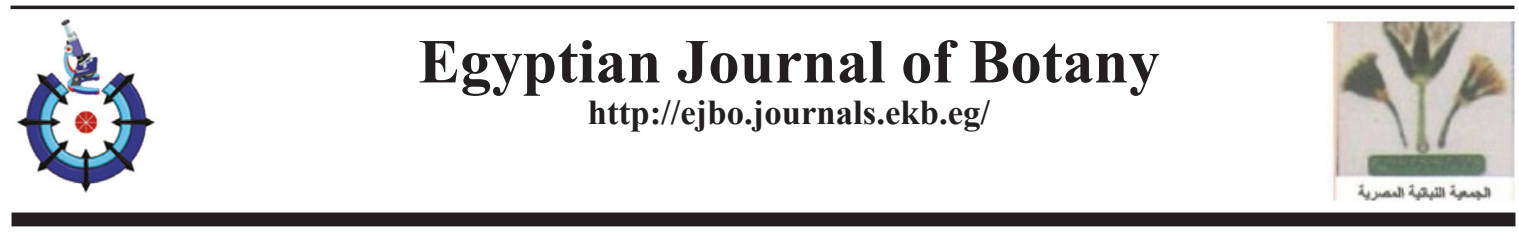

\title{
Fertilizing Potentiality of Fungal-Treated Olive Mill Solid Waste to improve Some Growth and Physiological Parameters of Vicia faba L.
}

Hanan Mahmoud Abou-Zeid\#, Salama El-Darier, Khaled Ghanem, Amr Salah Botany and Microbiology Department, Faculty of Science, Alexandria University, Alexandria, Egypt.

$\mathbf{T}$

HE MAIN objective of the present work is to biodegrade the phenols content of olive mill solid waste by a locally isolated fungus under optimized culture conditions and study the effect of the crude olive mill solid waste (OMSW), fermented olive mill solid waste (FOMSW), as well as the residue of water extracted olive mill solid waste (ROMSW) on some growth and physiological biomarkers of Vicia faba. Aspergillus tamarii was the most efficient fungus of ten isolated fungi, where it completely (100\%) degraded the phenolic contents of OMSW under the optimized culture conditions. Data showed that applying FOMSW and ROMSW resulted in a significant alleviation of OMSW adverse effects on plant shoots and roots, chlorophylls content, chlorophyll stability index, quantum yield of PSII (Fv/Fm), carbohydrates and protein content as well as the macro-elements $\mathrm{K}, \mathrm{P}, \mathrm{Mg}$ and $\mathrm{Ca}$ content. This improvement was increased with increasing concentrations of ROMSW, while it increased up to $4 \%$ of FOMSW. Even as the crude OMSW negatively affects the growth and physiological attributes of the tested plant, all treatments stimulated them. It seems that detoxification of OMSW either by A. tamarii or water resulted in a marked reduction of phenolics and rising in $\mathrm{pH}$ that might improve the soil characteristics and allows a secure and efficient dumping of OMSW.

Keywords: Biofertilizer, Biodegradation, Faba bean, Fungi, Phenolics, Photosynthesis.

\section{Introduction}

Olive production is considered as an important national income source for most Mediterranean countries (Nogueira et al., 2015). Oil extraction from olives produces large quantities of waste by-products that can destructively affect water resources, plants as well as soil microbes (Ahmed et al., 2019). Waste recycling is being applied to produce valuable fertilizers or amendments to improve the structure of the soil. The recycling of olive mill waste as organic compost can enhance soil fertility as well as reduce $\mathrm{CO}_{2}$ emissions. (Regni et al., 2017). The possibilities of these biomass waste sources as organic fertilizers have been evaluated by studying its effective management. The biomass waste contains valuable nutrients, which can be put to good use if managed properly (Chew et al., 2019).
Olive mill solid waste (OMSW) elicits a certain amount of toxicity owing to its phenolic constituents. OMSW has been considered as a potential source of pollution either in land or in water and great efforts have been applied to find lucrative solutions for its management (Marra et al., 2018). Several investigations have been carried out using microorganisms capable of growing aerobically on diluted OMSW with the objective of reducing its initial organic load and its phenolic content (Aggelis et al., 2003; Nogueira et al., 2015). Different chemical and biological treatment technologies have been employed for the reduction of phenol content in industrial wastes. The biological management has become helpful because of simplicity of the process, cost effectiveness, and its potentiality to bend toxic resources into secure products (Bramhachari et al., 2016; Youssef et al., 2019).

"Corresponding author email: hananmahmoud93@yahoo.com

Received 18/1/2020; Accepted 3/6/ 2020

DOI: 10.21608/ejbo.2020.22624.1441

Edited by: Prof. Dr. Salama A. Ouf, Faculty of Science, Cairo University, Giza 12613, Egypt.

(C)2020 National Information and Documentation Center (NIDOC) 
Different microbial strains can use the phenolic compounds present in OMSW as a carbon source for the production of different organic compounds useful in agricultural processes. Filamentous fungi (Aspergillus spp., Fusarium spp, etc.) have been used to degrade the phenolic compounds of industrial wastes such as OMW (Karatay \& Donmez, 2014). The fermented OMSW can be used as an organic biofertilizer instead of the traditional chemical fertilizers, also, it improves soil quality. Organic biofertilizers are not only a good source for plant nutrition but also they improve soil microbial activity and promote the activities of critical soil enzymes and plant growth hormones. Accordingly, they play a fundamental role in the ecosystem (Omer, 2012). Rhizosphere microorganisms have the impending to induce plant growth and help in managing plant diseases and abiotic stresses in the soil throughout the production of phytohormones and significant root morphological changes, which improve plantwater relations, nutritional status and stimulate the defensive mechanisms of plants (Goswami \& Deka, 2020).

Faba bean (Vicia faba L.) is considered as one of the most important legumes in Egypt. It has become one of the strategic crops due to its income to the farmers. Furthermore, faba bean is a popular legume food and used worldwide as an important source of protein for human and animal nutrition (Cazzato et al., 2012).

The main intent of the current work was to isolate and identify one local fungus efficient for degrading phenolic compounds dominant in OMSW. Furthermore, to study the effect of raw OMSW; fermentation residues (FOMSW) as well as residues of water extracted (ROMSW) on some growth biomarkers, physiological and biochemical analysis on Vicia faba L. to appraise its potentiality as a biofertilizer.

\section{Materials and Methods}

\section{Microbial preparation}

The tested fungi were isolated from OMSW and soil, purified, and identified according to Watanabe (2002) and CBS (2006). The medium that contains the best ingredients of the culture medium that favored the formation of enzyme system responsible for hydrolysis of OMSW phenols was $\left(\mathrm{g} \mathrm{L}^{-1}\right)$ : OMSW, 80; $\mathrm{K}_{2} \mathrm{HPO}_{4}, 3.40 ; \mathrm{KH}_{2} \mathrm{PO}_{4}$, 4.30; $\mathrm{MgSO}_{4} .7 \mathrm{H}_{2} \mathrm{O}, 0.30 ;\left(\mathrm{NH}_{4}\right)_{2} \mathrm{SO}_{4}, 1.0$; yeast extract, $0.05 ; 10 \mathrm{ml}$ of trace elements solution $\left(\mathrm{mg} \mathrm{L} \mathrm{L}^{-1}\right)$ of $\mathrm{MnCl} .4 \mathrm{H}_{2} \mathrm{O}, 1.0 ; \mathrm{FeSO}_{4} .7 \mathrm{H}_{2} \mathrm{O}$, 0.6; $\mathrm{CaCl}_{2} . \mathrm{H}_{2} \mathrm{O}, 2.6 ; \mathrm{Na}_{2} \mathrm{MoO}_{4} .2 \mathrm{H}_{2} \mathrm{O}, 6$ (Santos $\&$ Linardi, 2004). For optimization of medium composition and cultural conditions, two-phase optimization approach was carried out, the first deals with evaluating the significance of the different fermentation medium constituents and culture conditions using the Plackett-Burman design (Plackett \& Burman, 1946). Response surface methodology (Box \& Bhenken, 1960) was applied to determine the optimal level of each key independent variables and their interaction.

\section{Olive mill solid waste}

The OMSW was collected from three olive mills located at Dabaa area-western coastal region of Egypt. Recently produced OMSW was moved shortly to the laboratory, before use it was dried and passed through sieve $(2 \mathrm{~mm})$. Three groups were prepared: crude olive mill solid waste (OMSW), residue of water extracted olive mill solid (ROMSW) and fermented olive mill solid waste (FOMSW).

\section{Preparation of aqueous extract}

Stock aqueous extract (OMSWAE) and subsequent dilutions were obtained by the following methods: $1000 \mathrm{ml}$ of distilled water were mixed with $100 \mathrm{~g}$ dried OMSW, conducted in dark for $24 \mathrm{hrs}$ at $25^{\circ} \mathrm{C}$, centrifuged for $15 \mathrm{~min}$ at $5000 \mathrm{xg}$. The supernatant was adjusted to $\mathrm{pH} 6.8$; this would be $(100 \%)$ full strength concentration. Sequences of dilutions (0, 5, 10, 20 and 40\%) were equipped from the stock solution (El-Darier et al., 2015).

\section{Germination bioassay}

Petri-dish experiment was applied to investigate the biological activity of OMSWAE on faba bean plumule (PL) and radicle lengths (RL), fresh weight (FW) and dry weight (DW). Prior to germination, seeds were drenched $2 \mathrm{~min}$ in $2 \%$ chlorex for sterilization, after washed by distilled water numerous times. Finally, the seeds were soaked in aerated distilled water for $24 \mathrm{hrs}$, ten seeds were regularly arranged in Petri-dishes $(15 \mathrm{~cm}$ diameter) lined by two discs of Whatman No.1 filter paper under normal laboratory conditions. Ten $\mathrm{ml}$ of the $\operatorname{OMSWAE}(0,5,10,20$ and $40 \%$ ) were added daily. Inhibition percentage (IP) was calculated according to Zhen et al. (2008):

$$
\mathrm{IP}=[1-(\text { Treatment/Control })] \times 100 .
$$




\section{Growth bioassay}

To test the potential effects of OMSW, ROMSW and FOMSW on some growth and physiological attributes of faba bean, pot experiment was achieved for two weeks. At the end of the experiment, homologous faba bean individuals were harvested, washed with distilled water and finally separated into roots and shoots.

The three groups of waste were mixed with a sandy clay loam soil at different concentrations (2, 4, 8 and 16\%). One treatment containing untreated soil was used as a control. Soils in the plastic pots $(20 \mathrm{~cm}$ diameter, $21 \mathrm{~cm}$ length) were compacted to about field density. Ten sterilized faba bean seeds were planted in each pot. The pots were kept under normal laboratory conditions, and watered every two days (at 70\% field capacity) with tap water.

\section{Physiological and biochemical analysis}

Determination of photosynthetic pigments

Leaf chlorophyll extraction was prepared using N,N-dimethyl formamide $(4 \mathrm{ml})$ for $24 \mathrm{hrs}$ at $4^{\circ} \mathrm{C}$. Chlorophylls content was quantitatively determined using a spectrophotometer-double beam (T80 UV-Vis) at wave lengths of 646.8 and 663.8nm (Porra, 2002). Total carotenoids content was calculated according to Moran (1982). Chlorophyll stability index (CSI \%) was measured using the formula noted by Sivasubramaniawn (1992):

(Total Chl. in treated leaves/ Total Chl. in control leaves) $\times 100$.

\section{Fm) \\ Measurement of quantum yield of PSII (Fv/}

Chlorophyll fluorescence measurements were performed with chlorophyll fluorimeter OS-30P pulse modulated (Opti-sciences, Hudson, and USA) following the procedure described by (Branquinho et al., 1997). Leaves were darkadapted for $30 \mathrm{~min}$ with leaf-clips before each measurement.

Extraction and estimation of total available carbohydrates (TAC)

The powdered plant material $(100 \mathrm{mg})$ was introduced into a boiling tube, ten $\mathrm{ml}$ of $0.7 \mathrm{~N}$ $\mathrm{HCl}$ were then added and the tube was placed in a boiling water bath for $30 \mathrm{~min}$. The hydrolysate was neutralized and adjusted to known volume. TAC was estimated following the method described by Murata et al. (1968).

Extraction and estimation of total protein (TP)

Total protein was extracted by adding $10 \mathrm{ml}$ of $0.5 \mathrm{~N} \mathrm{NaOH}$ to about $100 \mathrm{mg}$ of the ovendry plant material which was left over night. After centrifugation the extract was completed to volume with distilled water (Rausch, 1981). Estimation of total protein was done as the method explained by Hartree (1972).

Extraction and estimation of total phenolics

Total phenolics content was estimated according the method of Demiray et al. (2009). Samples and standard absorbance was measured using spectrophotometer-double beam (T80 $\mathrm{UV}-\mathrm{Vis}$ ) at $765 \mathrm{~nm}$.

Energy dispersive spectroscopy (EDS) for elements analysis

Elemental analysis was carried out using an Energy Dispersive X-ray Fluorescence (EDS) spectrometer at the special unit of Electron Microscope, Faculty of Science, Alexandria University. Link ISIS analyzer programmed attached with Scanning Electron Microscope (JSM-5300) was employed for the data collection. Elements values correspond to the average of three replicate spectra attained from each tissue and each treatment (Chen et al., 2014).

\section{Statistical analysis}

Results of statistical analyses were carried out according to Duncan's multiple range tests using SPSS-20. Following the method described by Sokal \& Rohlf (1995), data were subjected to one-way ANOVA. Differences between treatment-means were considered statistically significant at $\mathrm{P} \leq 0.05$.

\section{Results}

\section{Microbial bioremediation of OMSW}

It was carried out to get rid and/or degrade phenolic compounds and other toxic materials that render its use as a biofertilizer and the fungal cell contents may add beneficial substances to the plant growth. This goal of work was started by isolation and identification of some fungi from OMSW and soil. Aspergillus tamarii was the most efficient in degradation of phenols $(64.07 \%)$ from the initial content $8.46 \mathrm{~g} \mathrm{~kg}^{-1}$. While the other tested fungi showed different 
activities of phenols degradation. In an attempt to maximize phenol degradation by the experimental fungus (A. tamarii), different six culture media with varied ingredients (qualitatively and quantitatively) were tested. The best medium was used as basal medium for phenol degradation. The time course study of phenols of OMSW degradation by $A$. tamarii indicated that 7 days of incubation represent the best growth period for $A$. tamarii to produce phenols hydrolyzing enzymes, at that period $84.6 \%$ of phenols were degraded.

In order to optimize degradation of phenols content of OMSW by the tested fungus, statistical experimental designs was applied. Two-phase optimization approach was carried out, the first deals with evaluating the significance of the different fermentation medium constituents and culture conditions using the Plackett-Burman design of the tested 14 trails, the medium consists of $\left(\mathrm{g} \mathrm{L}^{-1}\right)$ : OMSW, 80; $\mathrm{K}_{2} \mathrm{HPO}_{4}, 3.40 ; \mathrm{KH}_{2} \mathrm{PO}_{4}$, 4.30; $\mathrm{MgSO}_{4} .7 \mathrm{H}_{2} \mathrm{O}, 0.30 ;\left(\mathrm{NH}_{4}\right)_{2} \mathrm{SO}_{4}, 1.0$; yeast extract, $0.05 ; \mathrm{MnCl} .4 \mathrm{H}_{2} \mathrm{O}, 10.0(\mu \mathrm{g}) ; \mathrm{FeSO}_{4} .7 \mathrm{H}_{2} \mathrm{O}$, $0.6(\mu \mathrm{g}) ; \mathrm{CaCl}_{2} \cdot \mathrm{H}_{2} \mathrm{O}, 26(\mu \mathrm{g}) ; \mathrm{Na}_{2} \mathrm{MoO}_{4} \cdot 2 \mathrm{H}_{2} \mathrm{O}$, $100(\mu \mathrm{g})$; inoculum size $3 \mathrm{ml}\left(6 \times 10^{6}\right.$ spores $\mathrm{ml}^{-}$ $\left.{ }^{1}\right)$ and $25 \mathrm{ml} \mathrm{medium} / 250 \mathrm{ml}$ Erlenmeyer flasks, shacked at $180 \mathrm{rpm}$ for 7 days at $30 \pm 2^{\circ} \mathrm{C}$ and initial pH 6 appeared to be optimum for phenols degradation (96.28\%) that represent about 14\% increase as compared to the best tested medium for phenols degradation. Thereafter, response surface methodology was applied to determine the optimal level of each key independent variable and their interaction. The most significant variables included, medium volume $/ 250 \mathrm{ml}$ Erlenmeyer flask $\mathrm{Na}_{2} \mathrm{MoO}_{4} \cdot 2 \mathrm{H}_{2} \mathrm{O}$ and $\left(\mathrm{NH}_{4}\right)_{2} \mathrm{SO}_{4}$.

Ten trails were made and the results analyzed mathematically revealed an optimum response of the following concentrations: $\left(\mathrm{NH}_{4}\right)_{2} \mathrm{SO}_{4}, 1.8 \mathrm{~g} \mathrm{~L}^{-1}$; $\mathrm{Na}_{2} \mathrm{MoO}_{4} \cdot 2 \mathrm{H}_{2} \mathrm{O}, 60 \mu \mathrm{g} \mathrm{\textrm {L } ^ { - 1 }}$ and medium volume $17 \mathrm{ml}$ /flask with phenol degradation of $100 \%$ after $138 \mathrm{hrs}$ (5.75 days) instead of $168 \mathrm{hrs}$ ( 7 days). So under the optimized conditions, phenol content $\left(8.46 \mathrm{~g} \mathrm{~kg}^{-1}\right)$ of OMSW was completely degraded by $A$. tamarii after $138 \mathrm{hrs}$ of incubation. The results revealed that phenols content $8.46 \mathrm{~g} \mathrm{~kg}^{-1}$ was completely degraded, total carbohydrates recorded decrease and total lipids were significantly reduced. On the other hand, the total protein content has a significant increases and $\mathrm{pH}$ becomes neutral (Under publication). These results indicated that it is safe to use the fermented OMSW (FOMSW) as a biofertilizer.

\section{Germination bioassay}

The effect of different concentrations of olive mill solid waste aqueous extract (OMSWAE) on faba bean seeds was evaluated (Fig. 1). PL and RL lengths, as well as their FW and DW, were notably decreased with the increase in OMSWAE concentration.
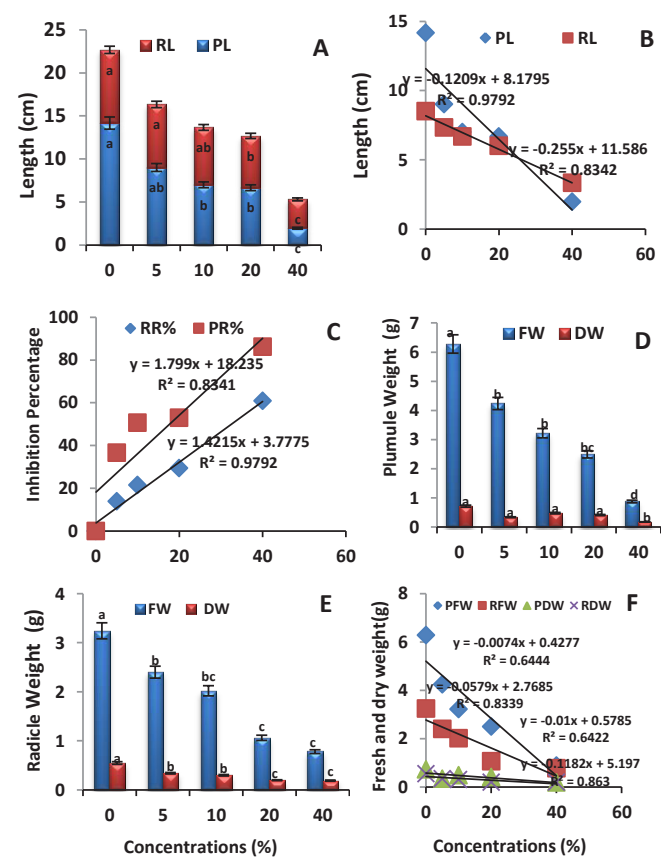

Fig. 1. Effect of different concentrations of OMSWAE on (A) radicle length (RL) and plumule length (PL), (B) regression analysis for radial and plumule lengths, $(C)$ reduction percentages of radicle and plumule lengths, (D) plumule fresh and dry weights, (E) radicle fresh and dry weights and (F) regression analysis of plumule and radicle fresh and dry weights of Vicia faba L. at 9 day-old seedlings [Values are means \pm SD based on triplicate independent determinations, and different letters mean significant difference as evaluated by Duncan's multiple comparison test].

\section{Growth bioassay}

A pot experiment was carried out by application of three treatments (OMSW, ROMSW, and FOMSW) of olive mill solid waste with different concentrations $(2,4,8$, and $16 \%$ ) mixed with sandy clay loam soil.

\section{Root and shoot lengths}

Generally, a $2 \%$ concentration level of OMSW showed a slight increase in root and shoot lengths of faba bean compared to control 
(Table 1). Conversely, the lengths of the two organs significantly decreased to values of 5.3 and 8.3 , respectively, relative to the control (6.25 and $16.5)$ in response to higher concentration $(16 \%)$. Detoxification by water extraction (ROMSW) significantly enhanced shoot and root lengths in all concentrations. At $16 \%$ of ROMSW concentration, the increase in both shoot and root lengths attained nearly 2 -fold more than the control. The root and shoot lengths of faba bean plants grown in soil mixed with OMSW fermented by Aspergillus tamarii showed a significant increase at low concentrations ( 2 and $4 \%$ ) compared to the control, on the other hand, high concentration showed a marked inhibition. Furthermore, the application of OMSW, ROMSW, and FOMSW at different concentrations significantly increased root: shoot $(\mathrm{R} / \mathrm{S})$ ratio in faba bean plants.

\section{Fresh $(F W)$ and dry $(D W)$ weights}

Data presented in Table 1 showed that mixing soil with different concentrations of raw OMSW resulted in a significant reduction of FW and DW. Mixing soil with the ROMSW showed an increase in the fresh and dry weights of shoots, while the two estimates for roots were reduced nearly by 33 and $17 \%$, respectively, at $16 \%$ concerning the control. It is clearly demonstrated that there was a gradual increase to $8 \%$ in the $\mathrm{FW}$ and $\mathrm{DW}$ of shoots and roots in soil containing A. tamariiFOMSW. Treatment with 4\% FOSMW resulted in a significant increase in shoots and roots, the increase values for FW reached about 1.6- and 1.9fold, respectively, and the corresponding values for DW were 1.6- and 2.3-fold, respectively.

\section{Photosynthetic pigments}

Data in Fig. 2 revealed that the total chlorophylls content was significantly decreased by increasing concentrations of OMSW comparing to untreated plants. The total chlorophylls contents estimated at $16 \%$ were reduced by $52 \%$ and chlorophyll stability index (CSI) reached $48 \%$ compared to control plants, whereas the corresponding value was $113 \%$ in ROMSW-treated plants (Fig. 2). The increase in Chl. a and Chl. b was significantly noticed in accordance with the increase in ROMSW concentrations reached about 1.13-fold and 1.06, respectively, at $16 \%$. Application of FOMSW enhanced the synthesis of photosynthetic pigments particularly at the concentration of $4 \%$ and the CSI value was $117 \%$. The trend of carotenoids content was significantly increased with increasing concentrations for all treatments.

TABLE 1. Effect of different concentrations of olive mill solid waste (OMSW), residue of water extracted olive mill solid waste (ROMSW), and fermented olive mill solid waste with Aspergillus tamarii (FOMSW ) on

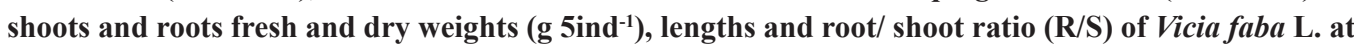
15 day-old plants.

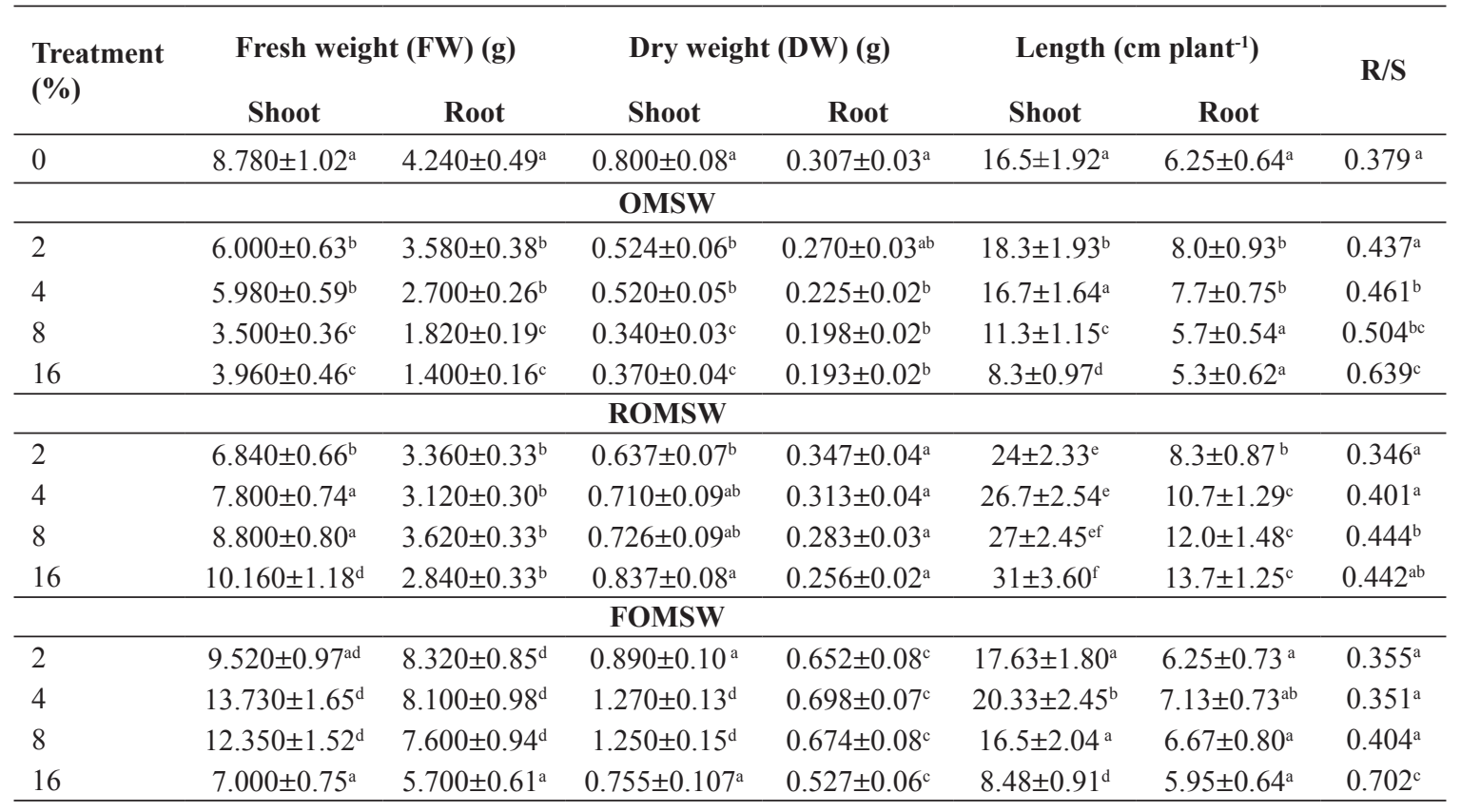

Values are means \pm SD based on triplicate independent determinations, and different letters mean significant difference as evaluated by Duncan's multiple comparison test. 

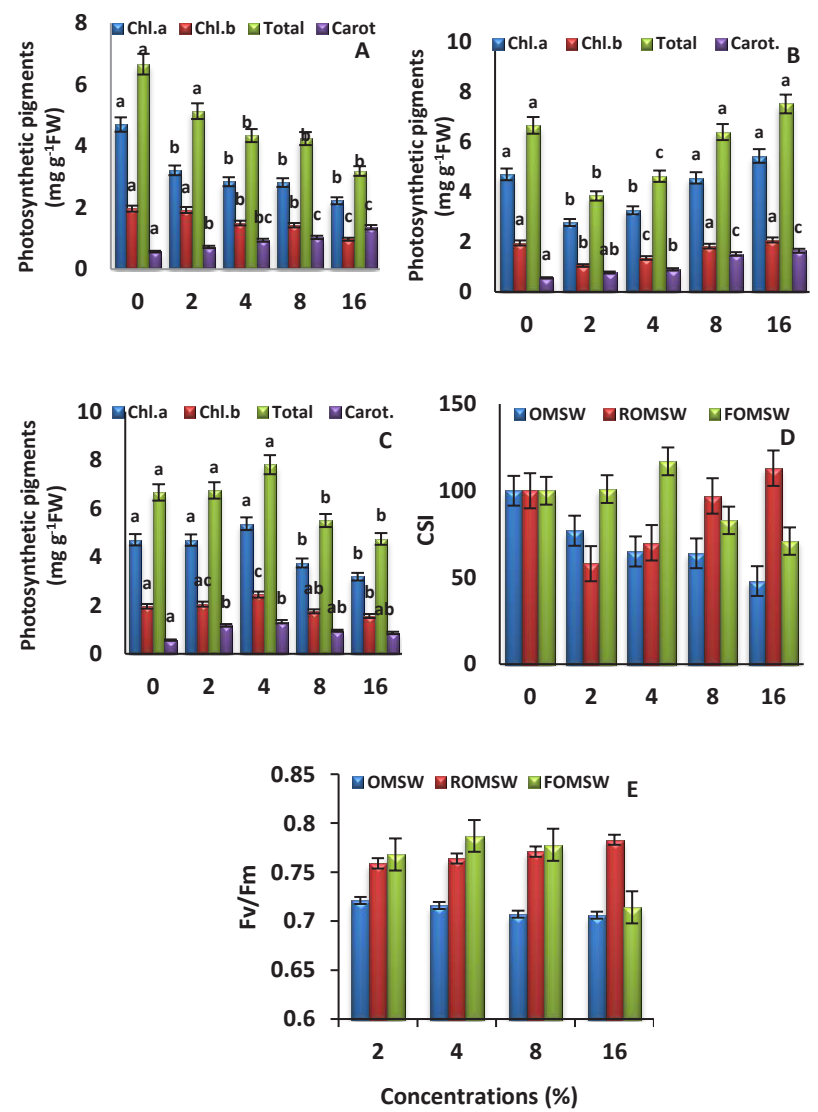

Fig. 2. Effect of different concentrations of (A) olive mill solid waste (OMSW), (B) residue of water extracted olive mill solid waste (ROMSW), and (C) fermented olive mill solid waste with Aspergillus tamari (FOMSW) on photosynthetic pigments content, chlorophyll stability index (D) and (E) quantum yield of PSII (Fv/Fm) of Vicia faba L. at 15 day-old plants [Values are means \pm SD based on triplicate independent determinations, and different letters mean significant difference as evaluated by Duncan's multiple comparison test].

\section{Measurement of quantum yield of PSII ( $F v / F m)$}

The maximal photochemical efficiency of PSII $(\mathrm{Fv} / \mathrm{Fm})$ decreased by increasing concentrations of OMSW, the reduction percentage was $10 \%$ compared to the control in leaves treated with 16\% OMSW (Fig. 2E). Applications of ROMSW resulted in a slight reduction with increasing concentrations, attained a similar value of control at $16 \%$, otherwise leaves treated with FOMSW showed a higher value at $4 \%$.

\section{Total available carbohydrates and total protein}

A significant reduction in TAC content was detected in OMSW- treated shoots and roots. The decrease in TAC was relatively prominent at high concentrations of crude OMSW-treated plants. The reduction percentage at 16\% achieved 33 and $38 \%$ for shoots and roots, respectively, compared to the control. On contrary, ROMSW treated plants at $16 \%$ showed a significant increase in TAC with increasing concentrations the values were 2-fold and 1.6-fold higher for shoots and roots respectively, concerning untreated plants. At $4 \%$ of FOMSW, the increase in shoots and roots was 1.3-fold and 1.1-fold, respectively, (Fig. 3E). The total protein content was significantly affected by applying the different concentrations of OMSW, commonly; there was a general trend of decrease in the content of TP with increasing waste concentrations. The reduction values recorded for the TP at the highest concentration were about $11 \%$ and $17 \%$ for shoots and roots, respectively, compared with the control. Application of ROMSW showed a notable increase in TP content with increasing waste concentrations in both shoots and roots. At $16 \%$, for example, the increase values were about 1.6- and 1.8-fold in shoots and roots, respectively. Likewise, the application of FOMSW on faba bean plants resulted in a significant increase in TP reaching the highest value at $4 \%$ in shoots (1.7-fold) as presented in Fig. 3F. 

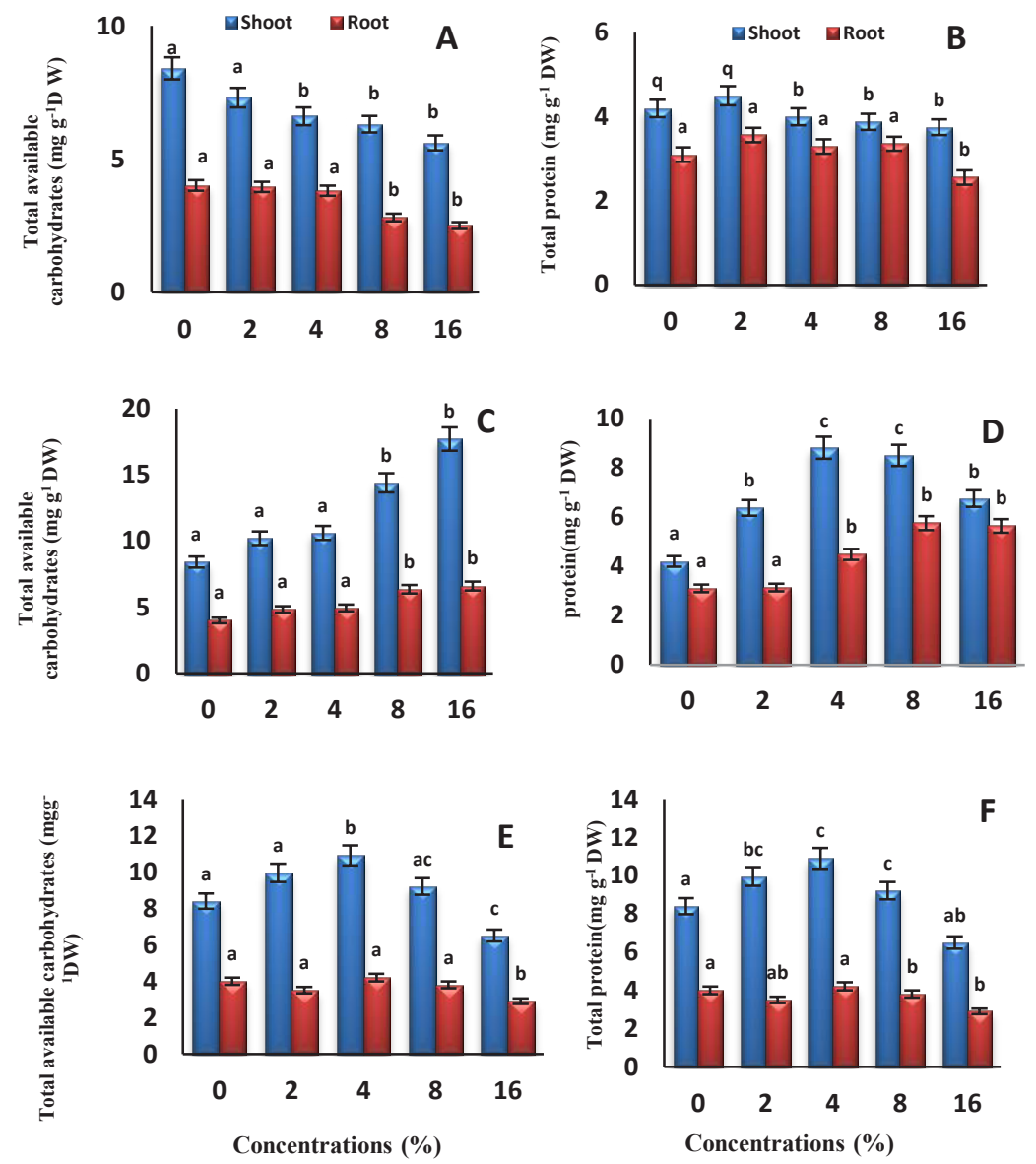

Fig. 3. Effect of different concentrations of (A \& B) olive mill solid waste (OMSW), (C \& D) residue of water extracted olive mill solid waste (ROMSW), and (E \& F) fermented olive mill solid waste with Aspergillus tamari (FOMSW) on total available carbohydrates and total protein content ( $\left.\mathrm{mg} \mathrm{g}^{-1} \mathrm{DW}\right)$ of Vicia faba $\mathrm{L}$. at 15 day-old shoots and roots [Values are means \pm SD based on triplicate independent determinations, and different letters means significant difference as evaluated by Duncan's multiple comparison test].

\section{Total phenolics}

The variation in total phenolics content of control and treated samples showed significantly increased values in shoots of faba bean grown in the three treatments compared to that of control (Fig. 4A). Total phenolic content of control samples was $3.96 \mathrm{mg} \mathrm{g}^{-1} \mathrm{DW}$ and that of treated shoots was $6.6,8.57$ and $10.67 \mathrm{mg} \mathrm{g}^{-1} \mathrm{DW}$ for the concentration of $16 \%$ mixed waste with the soil of OMSW, ROMSW, and FOMSW, respectively. Faba bean plants grown in soil mixed with ROMSW or FOMSW exhibited a significant accumulation of total phenolic compounds in the shoots; the accumulation increased in accordance with waste concentration. Application of regression analysis resulted in a value of coefficient $\left(\mathrm{R}^{2}\right)$ of determination of about $0.89,0.75$ and 0.78 , for OMSW, ROMSW, and FOMSW, respectively (Fig. 4B).
Energy dispersive spectroscopy (EDS) for elements analysis

The results of elemental analysis such as $\mathrm{Na}$, $\mathrm{Mg}, \mathrm{P}, \mathrm{K}, \mathrm{Ca}, \mathrm{Fe}, \mathrm{Cu}$ and $\mathrm{Zn}$ showed that the application of OMSW, ROMSW, and FOMSW caused variations in element percentages compared to the control (Fig. 5 and Table 2). A marked increase in the percentage of $\mathrm{K}, \mathrm{P}, \mathrm{Ca}$, and $\mathrm{Mg}$ was recorded in plants treated with ROMSW and FOMSW, the increasing values of $\mathrm{K}$ were nearly about 1.1- and 1.2 - fold, respectively compared to the control. Conversely, a great reduction of $\mathrm{K}$ percentage in plants treated with OMSW was detected; the percent inhibition was $23 \%$. There was a noticeable increase in microelements $\mathrm{Cu}$ and $\mathrm{Zn}$ in shoots of faba bean- treated with OMSW, the increase values were 2.5 and 1.7 - fold, respectively compared to the control. 

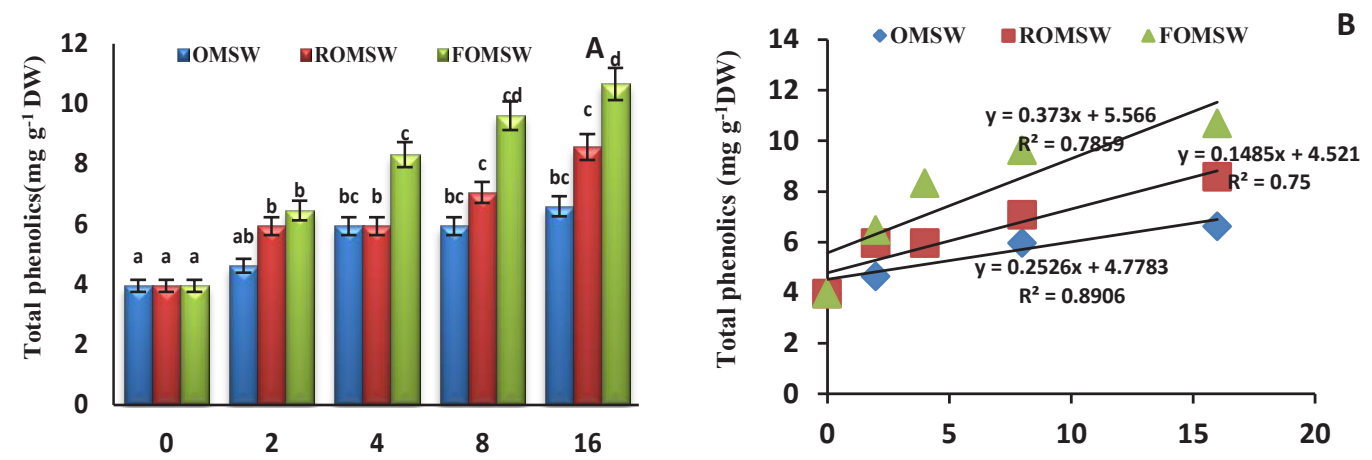

Concentrations (\%)

Fig. 4. Effect of different concentrations of olive mill solid waste (OMSW), residue of water extracted olive mill solid waste (ROMSW), and fermented olive mill solid waste with Aspergillus tamarii (FOMSW) on (A) total phenolics and (B) regression analysis of Vicia faba $\mathrm{L}$. at 15 day-old shoots [Values are means \pm SD based on triplicate independent determinations, and different letters mean significant difference as evaluated by Duncan's multiple comparison test].
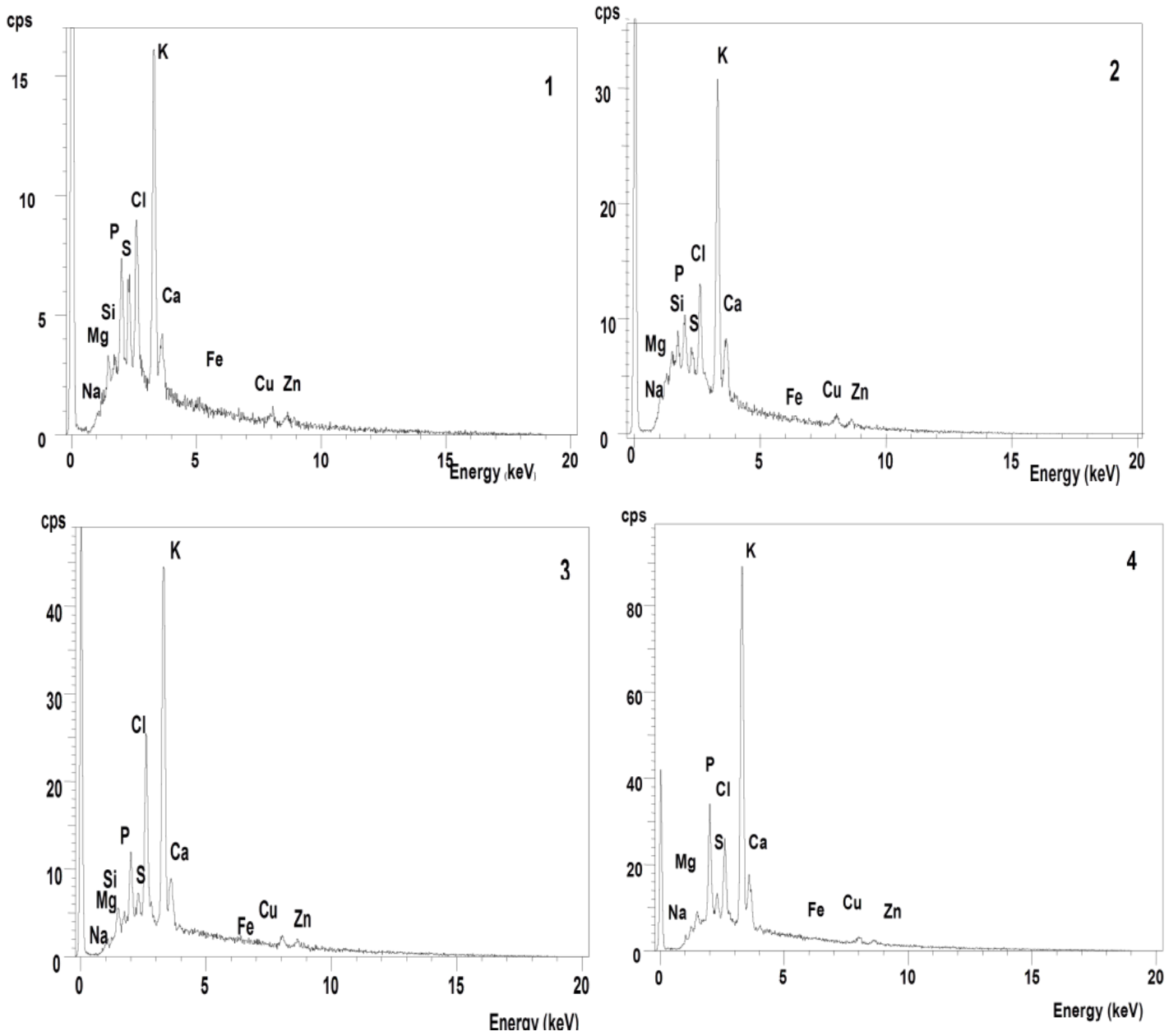

Fig. 5. The energy dispersive spectroscopic (EDS) analysis of elements in 15 day-old Vicia faba shoots of untreated (1) and treated with $8 \%$ (2) olive mill solid waste (OMSW), (3) residue of water extracted olive mill solid waste (ROMSW), and (4) fermented olive mill solid waste with Aspergillus tamari (FOMSW). 
TABLE 2. The percentages of elements in 15 days-old Vicia faba shoots of untreated (1) and treated with $8 \%$ (2) olive mill solid waste (OMSW), (3) residue of water extracted olive mill solid waste (ROMSW), and (4) fermented olive mill solid waste with Aspergillus tamarii (FOMSW).

\begin{tabular}{lcccc}
\hline \multirow{2}{*}{ Treatment elements } & Control & OMSW & ROMSW & FOMSW \\
\cline { 2 - 4 } & & \multicolumn{2}{c}{ Element concentration in \% } & \\
\hline $\mathrm{Na}$ & 0.8 & 2.1 & 0.9 & 0.7 \\
$\mathrm{Mg}$ & 2.6 & 1.9 & 4.9 & 4.3 \\
$\mathrm{Si}$ & 6.2 & 11.4 & 4.3 & 2.9 \\
$\mathrm{P}$ & 9.5 & $7 . .9$ & 10.9 & 11.5 \\
$\mathrm{~S}$ & 4.8 & 4.8 & 2.2 & 3.0 \\
$\mathrm{Cl}$ & 16.5 & 18.9 & 11.7 & 11.7 \\
$\mathrm{~K}$ & 43.4 & 33.5 & 48.8 & 50.7 \\
$\mathrm{Ca}$ & 9.0 & 5.7 & 11.5 & 10.4 \\
$\mathrm{Fe}$ & 1.3 & 3.0 & 1.6 & 1.1 \\
$\mathrm{Cu}$ & 1.5 & 3.7 & 1.8 & 1.0 \\
$\mathrm{Zn}$ & 1.8 & 3.0 & 1.4 & 0.7 \\
\hline
\end{tabular}

\section{Discussion}

Much consciousness towards sustainability and technological advances for solid waste management has been implemented to reduce the generation of unnecessary waste, particularly in developing countries. The recycling of this waste is being applied to produce valuable organic matter, which can be used as fertilizers or amendments to improve the soil structure (Chew et al., 2019). OMSW is very rich in organic matter (73.24\%) comprising of a relatively large amount of lignin, cellulose, hemicelluloses, lipids, and carbohydrates as well as phenolics $(8.46 \mathrm{~g} \mathrm{~kg}$ ${ }^{1}$ ). The electrical conductivity is about $6 \mathrm{dSm}^{-1}$ and the acidic $\mathrm{pH}$ value is about 5.1. OMSW possesses considerable amounts of mineral nutrients such as nitrogen, phosphorous, potassium, sodium, calcium, magnesium, iron, copper, manganese and zinc (ElDarier et al., 2015)

In the Mediterranean basin, the most serious environmental problem associated with the agro-industrial sector is the disposal of OMSW. Numerous organic and inorganic compounds were detected in OMSW in high concentrations. The phenolic compounds seem to be responsible for OMSW phytotoxicity and microbial inhibition (Ammar et al., 2005). These render its use as soil fertilizer where it is toxic to plants, animal cells and microorganisms (Mekki et al., 2006). Crude OMSW has insufficiently stable matter, and when applied to soil, it may induce a number of negative effects on the soil properties and plant growth (Komilis et al., 2005). OMSW before its application to the soil might be, consequently, subjected to suitable treatments for stabilization of its organic amendments, and diminshing its environmental hazard (Brunetti et al., 2007). Several treatments have been projected to reduce the toxicity of OMSW phenolic content of which the most promising is the use of microorganisms capable of degrading its phenol content (Hamdi et al., 1991; Mechri et al., 2011). In this respect, the bioremediation of OMSW using specific strains of fungi has been used. Additionally, the ability of fungi to degrade different phenolic compounds was reported (Ghanem et al., 2009; 2013).

Data of the current study revealed that the proximate chemical analysis of the fermented OMSW as compared to crude OMSW indicated that the $\mathrm{pH}$ value of the fermented waste tends to be neutral ( $\mathrm{pH} \mathrm{7)}$ which is due to the different metabolic activities of $A$. tamarii. The acidity of crude OMSW may be due to its content of organic acids and other compounds (Garcia et al., 2000). Paredes et al. (2000) found that the $\mathrm{pH}$ of OMSW was 5.17. The neutral $\mathrm{pH}$ value of the FOMSW favors its use as a fertilizer than the acidic $\mathrm{pH}$ value of crude waste. The total carbohydrates of crude OMSW were noticeably reduced (3.5 fold decrease) after fermentation; this indicates that $A$. tamarii assimilated most of $(71.4 \%)$ total carbohydrates during its fermentation process. However, the total proteins showed about a $27.7 \%$ increase, due to the fungal content of proteins. As for the total lipids (oils), it was markedly decreased from $16.5 \mathrm{~g} \mathrm{~kg}^{-1}$ to $1.0 \mathrm{~g} \mathrm{~kg}^{-1}$, this indicates that $A$. 
tamarii assimilated the crude OMSW oils, and so, it has lipases. In accordance, Dayanandan et al. (2012) reported that that $A$. tamarii has lipases. The chemical analysis of OMSW for lipids, polyphenols and carbohydrates content was concomitant with that recorded by Filidei et al. (2003).

The affiliated aim in the current laboratory-scale study was to assess the effect of OMSW, FOMSW, and ROMSW on some physiological parameters to determine the most appropriate waste to increase soil fertility.

In the present study, the application of olivemill waste aqueous extract to the germinating Vicia faba L. seeds exhibited a severe reduction to PL and RL lengths with increasing the extract concentrations, which may be credited to the continuation of the phenolic compounds. It is known that OMSW suppresses seeds germination of different plant species (Niaounakis \& Hakvadakis, 2004). Massoudinejad et al. (2014) reported that the phytotoxic effects of the phenolic compounds contained within the OMSW had a bad impact on germination. Some plant extracts or residues may inhibit germination, emergence and subsequent growth of other plants by exuding toxic substances. These substances are called allelochemicals (Madany \& Khalil, 2017; Hassanein et al., 2019). When these allelochemicals are taken up by germinating seeds of the same or of other plant species, there may be some degrees of germination and emergence inhibition or growth injury (Hassanpouraghdam et al., 2010). Bora et al. (1999) found that the elongation of radicle and epicotyl was reduced in all treatments of Acacia auriculiformis extract proportional to the concentration levels, they suggested that the inhibitory effect was related to the presence of allelochemicals including tannins, wax, flavonoids and phenolic acids.

The use of OMSW has been seen to have a detrimental effect on faba bean growth. Increasing of OMSW concentrations (2, 4, 8, and 16\%) resulted in a marked reduction of length, fresh and dry weight of shoots and roots. This was accompanied by a notable decline of chlorophylls content, chlorophyll stability index, the efficiency of PSII (Fv/Fm), total available carbohydrates, total proteins, and the macro-elements $\mathrm{K}, \mathrm{P}, \mathrm{Mg}$ and $\mathrm{Ca}$ contents. These observations could be related to the phytotoxic effects of absorbed phenolic compounds and the inhibitory effect of accumulation of $\mathrm{Cu}$ and
$\mathrm{Zn}$ in faba bean shoots and roots. In agreement with these observations, Ouzounidou et al. (2008) reported that application of olive mill waste for tomato cultivation caused a significant limitation of absorption and translocation of $\mathrm{K}, \mathrm{Na}, \mathrm{Fe}, \mathrm{Ca}$, and $\mathrm{Mg}$, which caused deficiencies of those elements. Asfi et al. (2012) assessed that OMSW stress influences photosynthetic pigments and damages the photosynthetic apparatus. Additionally, Rocchetta \& Kupper (2009) reported that $\mathrm{Cu}$ and $\mathrm{Zn}$ stress resulted in the generation of reactive oxygen species (ROS) causing oxidative stress and inhibition of the photosynthetic machinery and, also, may have a phytotoxic effect limiting crop yield and quality. Under prevailing experimental conditions, total available carbohydrates and protein contents in the shoots and roots of OMSW-treated faba bean plants were significantly decreased with increasing the crude waste concentrations (Fig. 3), indicating the suppression of plant growth.

Ouzounidou et al. (2010) concluded that the inhibitory effects of olive mill waste on plant growth might be related to its high mineral salt content, low $\mathrm{pH}$ and the occurrence of phytotoxic compounds, particularly polyphenols. Similarly, the current study showed that OMSW was characterized by high mineral salts, low $\mathrm{pH}$ and high phenolics content (Rahmanian et al., 2014). Thus, the decrease in the growth of faba bean under prevailing experimental conditions might be attributed to the decrease in soil acidity and the increase of the phytotoxic effect of phenolics on plasma membrane integrity, as well as a disturbance in metabolic processes (Zhang et al., 2010).

Application of the ROMSW and FOMSW to the soil, improved the growth, chlorophyll contents, CSI, chlorophyll a fluorescence (Fv/ Fm), TAC, TP and macronutrient concentrations. This improvement was increased with increasing concentrations of ROMSW, while it increased up to $4 \%$ of FOMSW then gradually declined. These observations might be due to the increase in $\mathrm{K}$, $\mathrm{P}, \mathrm{Mg}$ and $\mathrm{Ca}$ contents and the decrease in $\mathrm{Cu}$ and $\mathrm{Zn}$ concentrations resulting in increasing the biosynthesis of photosynthetic pigments (Fig. 2) and hence improving the photosynthetic machinery, as well as shifting off the oxidative stress caused by $\mathrm{Cu}$ and $\mathrm{Zn}$. Efthimiadou et al. (2010) appraised that nutrients like $\mathrm{P}, \mathrm{K}$, and $\mathrm{Mg}$ improve the root growth, increase the intake of water which helps in stomatal regulation, also the photosynthetic rate and stomatal conductance of the corn plants. Under 
the prevailing experimental conditions, there was a marked increase of carotenoids and total phenolics contents with increasing the waste level in the soil. These findings could be attributed to the removal of generated ROS under waste treatment. Kalaji et al. (2012) confirmed that carotenoids are essential for the photoprotection of the photosynthetic apparatus.

It is shown that washing and A. tamariitreatment waste resulted in an increase in the $\mathrm{pH}$ from 5.1 to 6.8 and 7 , respectively, and decrease total phenolics from $8.46 \mathrm{~g} \mathrm{~kg}^{-1}$ to $2.5 \mathrm{~g} \mathrm{~kg}^{-1}$ and $0.0 \mathrm{~g} \mathrm{~kg}^{-1}$ waste, respectively. Consequently, the improvement of soil characteristics, due to washing or A. tamarii-treatment of waste, by increasing $\mathrm{pH}$ could be result in protecting the plasma membrane integrity and, hence, the growth. It is clearly demonstrated that treatment with FOMSW resulted in complete degradation of phenolics and raising the $\mathrm{pH}$. Accordingly, the application of FOMSW to the soil might improve the soil characteristics, in which raising $\mathrm{pH}$ and decreasing external phenolics. Kistner et al. (2004) reported that the addition of bio-OMWW resulted in significantly higher shoot length and the number of leaves, fresh weight of leaves stems and roots. Moreover, Ouzounidou et al. (2012) findings were that the bio-treated OMW alleviated the significant decrease in photosynthetic activity observed in raw OMW applications. Moreover, Salman et al. (2014) pointed out that bioremediation may produce valuable products including excellent fertilizer. Additionally, Anwar et al. (2015) and El-Darier et al. (2015) recorded that bio-degradable OMSW can successfully be cocomposted with different types of organic wastes to get a higher quality composted product. Recently, Regni et al. (2017) findings were that the recycling of the OMSW as a soil amendment is a win-win strategy to transform a potential environmental threat associated with its disposal into an important resource and to improve the soil quality.

Although, there was a marked increase of faba bean growth in A. tamarii-fermented waste, the growth decreased in high concentrations and this was accompanied by a significant increase of phenolics content in faba bean shoots. These findings could be related to the presence of some fungal metabolite (s) produced during the fermentation acting as toxic substances. Whereas, the increase of accumulated phenolics could be related to removing these toxic responsibilities as phenolic compounds are considered as a class of antioxidant agents and their antioxidative properties is due to their ability to chelate transition metal ion, the inhibition of superoxide-driven Fenton reaction (Luo et al., 2004).

\section{Conclusion}

The toxicity of phenolics and acidity of OMSWcontaminated soil might be considered important parameters as most polluting agents for inhibition of faba bean growth. According to this study OMSW detoxification (water or microbiologically) might result in a marked reduction of phenolics and rising in $\mathrm{pH}$ which allows safe and economical disposal of OMSW. Using A. tamarii in the current study, as a bio-degradable for OMSW resulted in the complete absence of the phytotoxic action of phenols leading to positive effects of detoxified OMSW, may be attributed to its effect on the increase in macronutrients $\mathrm{K}, \mathrm{P}, \mathrm{Mg}$ and $\mathrm{Ca}$ availability at the soil that act as bio-organic fertilizers that improve the plant growth.

Conflict of interests: No potential conflict of interest was reported by the authors.

Authors contribution: The authors confirm contribution to the paper as follows: Study conception and design: Ghanem K., El-Darier S., Abou-Zeid H.M., following lab experiments, data analysis and interpretation: Ghanem K., El-Darier S., Abou-Zeid H.M., Salah A., draft manuscript preparation: Abou-Zeid H.M., critical revision of the article and final approval of the version to be published: Ghanem K., El-Darier S., Abou-Zeid H.M.

Ethical approval: Not applicable.

\section{References}

Aggelis, G., Iconomou, D., Christou, M., Bokas, D., Kotzailias, S., Christou, G., Tsagou, V. and Papanikolaou, S. (2003) Phenolic removal in a model olive oil mill wastewater using Pleurotus ostreatus in bioreactor cultures and biological evaluation of the process. Water Research, 37, 3897-3904.

Ahmed, P.M., Fernández, P.M., Figueroa, L.I.C. and Pajot H.F. (2019) Exploitation alternatives of olive mill wastewater: Production of value added compounds useful for industry and agriculture. Biofuel Research Journal, 22, 980-994. 
Ammar, E., Nasri, M., Medhioub, K. (2005) Isolation of Enterobacteria able to degrade simple aromatic compounds from the wastewater of olive oil extraction. World Journal of Microbiology and Biotechnology, 21, 253-259.

Anwar, Z., Irshad, M. Fareed, I., Saleem, A. (2015) Characterization and Recycling of Organic Waste after Co-Composting -A Review. Journal of Agricultural Science, 7, 68-79.

Asfi, M., Ouzounidou, G., Panajiotidis, S., Therios, I., Moustakas, M. (2012) Toxicity effects of olive-mill wastewater on growth, photosynthesis and pollen morphology of spinach plants. Ecotoxicology and Environmental Safety, 80, 69-75.

Bora, I.P., Singh, J., Borthakur, R. and Bora, E. (1999) Allelopathic effect of leaf extracts of Acacia auriculiformis on seed germination of some agricultural crops. Annals of Forestry, 7, 143-146.

Box, G.E.P., Behnken, D.W. (1960) Some new three level designs for the study of quantitative variables. Technometrics, 2, 455-475.

Bramhachari, P. V., Reddy, D.R.S., Kotresha, D. (2016) Biodegradation of catechol by free and immobilized cells of Achromobacter xylosoxidans strain 15DKVB isolated from paper and pulp industrial effluents. Biocatalysis and Agricultural Biotechnology, 7, 36-44.

Branquinho, C., Brown, D.H., Catarino, F. (1997) The cellular location of $\mathrm{Cu}$ in lichens and its effect on membrane integrity and chlorophyll fluorescence. Environmental and Experimental Botany, 38, 165179.

Brunetti, G., Senesi, N., Plaza, C. (2007) Effects of amendment with treated and untreated olive oil mill wastewater on soil properties, soil humic substances and wheat yield. Geoderma, 138, 144-152.

Cazzato, E., Tufarelli, V., Ceci, E., Stellacci, A.M., Laudadio, V. (2012) Quality, yield and nitrogen fixation of faba bean seeds as affected by sulphur fertilization. Acta Agriculturce Scandinavica Section B, 62, 732-738.

CBS (2006.) Central Bureau voorschimmel culture identification common species Aspergillus available at: www.CBS.knaw.nl.
Chen, S., Diekmann, H., Janz, D., Polle, A. (2014) Quantitative X-ray elemental imaging in plant materials at the subcellular level with a transmission electron microscope: Applications and Limitations Materials, 7, 3160-3175.

Chew, K.W., Chia, S. R., Yen, H.W., Nomanbhay, S., Ho, Y.C. and Show, P.L. (2019) Transformation of biomass waste into sustainable organic fertilizers sustainability. MDPI, Open Access Journal, 11(8), 2266; doi:10.3390/su11082266.

Dayanandan, A., Rani, S.H.V., Shanmugavel, M., Gnanamani, A., Rajakumar, S.G. (2012) Solid state bioprocessing for scale up of Aspergillus tamarii MTCC5152 lipase and its degreasing effect on cow hide. Indian Journal of Science and Technology, 5(7), 2978-2983.

Demiray, S., Pintado, M.E., Castro, P.M.L. (2009) Evaluation of phenolic profiles and anti-oxidant activities of Turkish medicinal plants: Tiliaargentea, Crataegi folium leaves, and Polygonum bistorta roots. WASET, 54, 312-317.

Efthimiadou, A., Bilalis, D., Karkanis, A., FroudWilliams, B. (2010) Combined organic inorganic fertilization enhances soil quality and increased yield, photosynthesis and sustainability of sweet maize crop. Australian Journal of Crop Science, 9, 722-729.

El-Darier, S.M., Ahmed, H.A., Abd El Razik, M.S., Allam, M.E.S. (2015) detoxification of olive-mill solid waste and its probable application as organic fertilizer. Journal of Fertilizers \& Pesticides, 6(2), 154. doi:10.4172/2471-2728.1000154.

Filidei, S., Masciandaro, G., Ceccanti, B. (2003) Anaerobic digestion of olive oil mill effluents: Evaluation of wastewater organic load and phytotoxicity reduction. Water, Air, \& Soil Pollution, 145, 79-94.

Garcia, G.I., Pena, P.R.J., Venceslada, J.L.B., Martin, A.M., Santos, M.A.M., Gomez, E.R. (2000) Removal of phenol compounds from olive mill wastewater using Phanerochaete chrysosporium, A. niger, A. terreus and Geotrichum candidum. Process Biochemistry, 35, 751-758.

Ghanem, K.M., Al-Garni, S.M., Al-Shehri, A.N. (2009) Statistical optimization of cultural conditions by response surface methodology for phenol 
degradation by a novel Aspergillus flavusisolate. African Journal of Biotechnology, 8, 3576-3583.

Ghanem, K.M., Al-Fassi, F.A., Al-Hazmi, N.M. (2013) Optimization of chloroxylenol degradation by Aspergillus niger using Plackett-Burman design and response surface methodology. Romanian Biotechnological Letters, 18, 7983-7994.

Goswami, M., Deka, S. (2020) Plant growth-promoting rhizobacteria|alleviators of abiotic stresses in soil: A review. Pedosphere, 30, 40-61.

Hamdi, M., Khadir, A., Garcia, J.L. (1991) The use of Aspergillusniger for bioconversion of olive mill wastewater. Applied Microbiology and Biotechnology, 34, 828-831

Hartree, E.F. (1972) Determination of protein: A modification of the lowry method that gives a linear photometric response. Analytical Biochemistry, 48, 422-427.

Hassanein, R.A., Abdelkader, A.F., Faramawy, H.M. (2019) Moringa leaf extracts as biostimulantsinducing salinity tolerance in the sweet basil plant. Egyptian Journal of Botany, 59(2), 303-318.

Hassanpouraghdam, B.E., ZehtabSalmasi, S.M.B., Khatamian, O.S. (2010) Allelopathic effects of Xanthium strumarium L. shoot aqueous extract on germination, seedling growth and chlorophyll content of lentil (Lens culinaris Medic.). Romanian Biotechnological Letters, 15(3), 5223-5229.

Kalaji, H.M., Carpentier, R., Allakhverdiev, S.I., Bosa, K. (2012) Fluorescence parameters as early indicators of light stress in barley. Journal of Photochemistry and Photobiology, 112, 1-6.

Karatay, S.E., Donmez, G. (2014) An economical phenol bioremoval method using Aspergillus versicolor and agricultural wastes as a carbon source. Journal of Ecological Engineering, 73, 224-228.

Kistner, T. Nitz, G., Schnitzler, W.H. (2004) Phytotoxic effects of some compounds of olive mill wastewater (OMW). Fresenius Environmental Bulletin, 13, 1360-1361.

Komilis, D.F., Karatzas, E., Halvadakis, C.P. (2005) The effect of olive mill wastewater on seed germination after various pre-treatment techniques.
Journal of Environmental Management, 74, 339348.

Luo, Y., Cai, Q., Sun, M., Corke, H. (2004) Antioxidant activity and phenolic compounds of 112 traditional Chinese medicinal plants associated with anticancer. Life Sciences, 74, 2157-2184.

Madany, M.M.Y., Khalil R.R. (2017) Fenugreek seed extract enhanced the growth of vicia faba and zea mays seedlings. Egyptian Journal of Botany, 57(2), 363-377.

Marra, R., Vinale, F., Cesarano, G., Lombardi, N., d'Errico, G., Crasto, A., et al. (2018) Biochars from olive mill waste has contrasting effects on plants, fungi and phytoparasitic nematodes. PLOS ONE, 13(6), e0198728.

Massoudinejad, M.R., Arman, K., Aghayani, E. (2014) Ecological risk assessment to olive oil mill wastewater (OMW) with bioassay on plant species. Environmental Conservation, 20, 229-234.

Mechri, B., Cheheb, H., Boussadia, O., Attia, F., Ben Mariem, F., Brahamb, M., Hammami, M. (2011) Effects of agronomic application of olive mill wastewater in a field of olive trees on carbohydrate profiles, chlorophyll a fluorescence and mineral nutrient content. Environmental and Experimental Botany, 71, 184-191.

Mekki, A., Dhouib, A., Sayadi, S. (2006) Changes in microbial and soil properties following amendment with treated and untreated olive mill wastewater. Microbiological Research, 161(2), 93-101.

Moran, R. (1982) Formulae for determination of chlorophyllous pigments extracted with N,Ndimethyl formamide. Plant Physiology, 69, 1376 1381.

Murata,T., Odaka,Y., Uchino, K., Yakushiji, E. (1968) Reconstitution of the photosensitive form of Chenopodium chlorophyll protein from its apoprotein. In: "Comparative Biochemistry and Biophysics of Photosynthesis". Shibata, K., Takamiya, A., Jagendorf, A.T., Fuller, R.C. (Eds.), pp. 222-228. University of Tokyo Press, Tokyo.

Niaounakis, M., Halvadakis, C.P. (2004) Olive processing waste management: Literature review and patent survey. In: "Waste Management", Vol. 5, $2^{\text {nd }}$ ed., Elsevier, Amsterdam. 
Nogueira, V., Lopes, I., Freitas, A.C., Rocha-Santos, T.A.P., Gonçalves, F., Duarte, A.C., Pereira, R. (2015) Biological treatment with fungi of olive mill wastewater pretreated by photocatalytic oxidation with nanomaterials. Ecotoxicology and Environmental Safety, 115, 234-242.

Omer, A.M. (2012) Production of organic biofertilizer from olive mill waste water. Australian Journal of Basic and Applied Sciences, 6(10), 654-663.

Ouzounidou, G., Asfi, M., Sotirakis, N., Papadopoulou, P., Gaitis, F. (2008) Olive mill wastewater triggered changes in physiology and nutritional quality of tomato (Lycopersicon esculentum Mill.) depending on growth substrate. Journal of Hazardous Materials, 158, 523-30.

Ouzounidou, G., Zervakis, G.I., Gaitis, F. (2010) Raw and microbiologically detoxified olive mill waste and their impact on plant growth. Terrestrial and Aquatic Environmental Toxicology, 4, 21-38.

Ouzounidou, G. , Ntougias, S., Asfi, M., Gaitis, F., Zervakis, I. G. (2012) Raw and fungal-treated olivemill wastewater effects on selected parameters of lettuce (Lactuca sativa L.) growth-The role of proline. Journal of Environmental Science and Health, Part B, 47(7), 728-735.

Paredes, C., Roig, A. Bernal, M.P., Sanchez-Monedero, M.A., Cegarra, I. (2000) Evolution of organic matter and nitrogen during co-composting of olive mill wastewater with solid organic wastes. Biology and Fertility of Soils, 32, 222-227.

Plackett, R.L., Burman, J.P. (1946) The design of optimum multifactorial experiments. Biometrika, 33, 305-325.

Porra, R.J. (2002) The chequered history of the development and use of simultaneous equations for the accurate determination of chlorophylls $\mathrm{a}$ and $\mathrm{b}$. Photosynthesis Research, 73, 149-156.

Rahmanian, N., Jafari, S.M., Galanakis, C.M (2014) Recovery and removal of phenolic compounds from olive mill wastewater. Journal of the American Oil Chemists' Society, 91(1), 1-18.

Rausch, T. (1981) The estimation of micro-algal protein content and its meaning to the evaluation of algal biomass I. Comparison of methods for extracting protein. Hydrobiologia, 78, 237-251.
Regni, L., Nasini, L., Ilarioni, L., Brunori, A., Massaccesi, L., Agnelli, A., Proietti, P. (2017) long term amendment with fresh and composted solid olive mill waste on olive grove affects carbon sequestration by prunings, fruits, and soil. Frontiers in Plant Science, 7, 2042.

Rocchetta, I., Kupper, H. (2009) Chromium and copper induced inhibition of photosynthesis in Euglena gracilis analysed on the single-cell level by fluorescence kinetic microscopy. New Phytologist, 182, 405-420.

Salman, M., Abu-Khalaf, N., Abu Rumaileh, B., Jawabreh, M., Abuamsha, R. (2014) Detoxification of Olive Mill Wastewater Using the White Rot Fungus Phanerochaete chrysosporium. International Journal of Environment and Sustainability, 3(1), 1-6.

Santos, V.L., Linardi, V.R. (2004) Biodegradation of phenol by a filamentous fungi isolated from industrial effluents identification and degradation potential. Process Biochemistry, 39, 1001-1006.

Sivasubramaniawn, K. (1992) Chlorophyll stability index: methods for determining drought hardness of Acacia species. Nitrogen Fixing Tree Research Reports, 10, 111-112.

Sokal, R.R., Rohlf, F.J. (1995) "Biometry: The Principles and Practice of Statistics in Biological Research", ( $3^{\text {rd }}$ ed.). New York: W.H. Freeman Publishers.

Watanabe, T. (2002) "Pictorial Atlas of Soil and Seed Fungi". CRC press, $2^{\text {nd }}$ ed., pp. 190-196.

Youssef, M., El-Shatoury, EH., Ali, S.S., El-Taweel, E.G. (2019) Enhancement of phenol degradation by free and immobilized mixed culture of Providenciastuartii PL4 and Pseudomonas aeruginosa PDM isolated from activated sludge. Bioremediation Journal, 23(2), 53-71.

Zhang, T., Zheng, C., Hu, W., Xu, W., Wang, H. (2010) The allelopathy and allelopathic mechanism of phenolic acids on toxic Microcystis aeruginosa. Journal of Applied Phycology, 22, 71-77.

Zhen, A.N., Zhenyu, W.A.N., Fengmin, L.I., Zhijia, T.I.A., Hongying, H.U. (2008) Allelopathic inhibition on red tide microalgae Skeletonema costatum by five macroalgal extracts. Frontiers of Environmental Science \& Engineering in China, 2(3), 297-305. 


\title{
استخدام المخلف الصلب لعصر الزيتون كسماد لنبات الفول بعد ازالة سميته بالمعالجة
}

\section{بالفطريات}

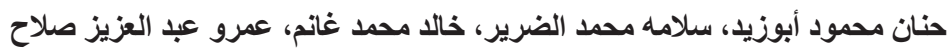
قسم النبات والميكروبيولوجي ـ كلية العلوم - جامعة الإسكندرية ـ الإسكندرية ـ مصر.

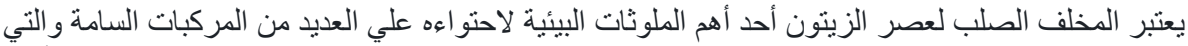

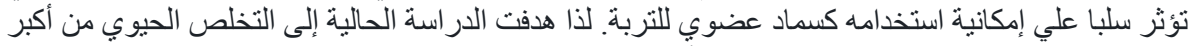

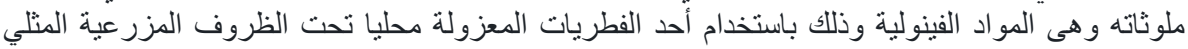

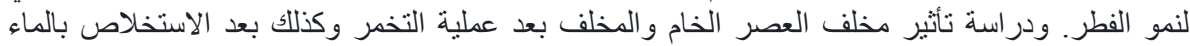

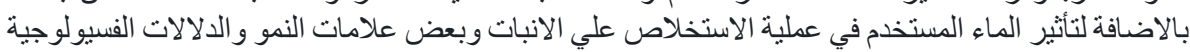

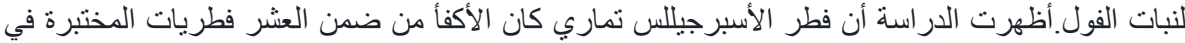

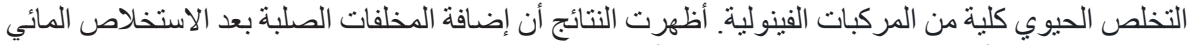

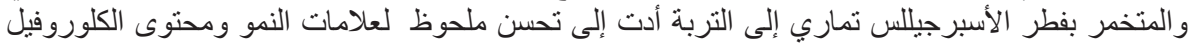

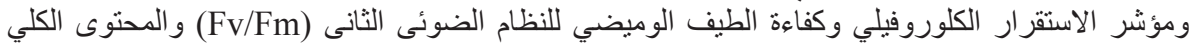

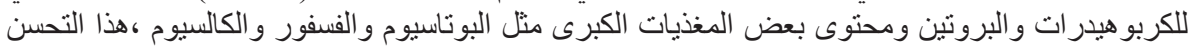

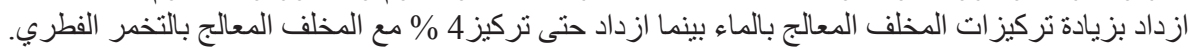

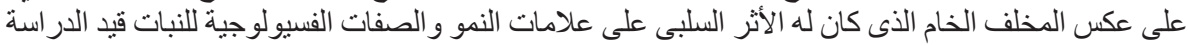

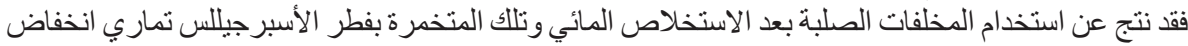

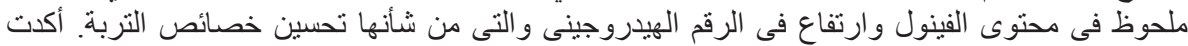

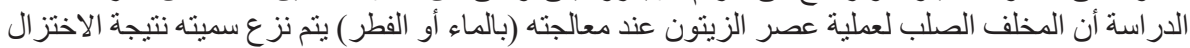

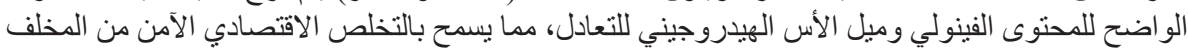

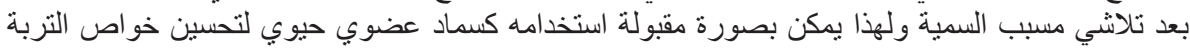
وبالتالي ندو النبات.
\end{abstract}

